\title{
Papilomatose confluente e reticulada de Gougerot e Carteaud: relato de três casos
}

\author{
Confluent and reticulated papillomatosis of Gougerot and Carteaud: \\ report of three cases
}

\author{
Leonardo Mello Ferreira ${ }^{1}$
}

\author{
Lucia Martins Diniz ${ }^{2}$
}

\author{
Carlos Jaques Mazzei Ferreira ${ }^{3}$
}

\begin{abstract}
Resumo: A papilomatose confluente e reticulada de Gougerot e Carteaud é dermatose rara, de etiologia obscura. Há diversas opções terapêuticas - retinóides tópicos e sistêmicos, antibióticos orais, entre outros - a maioria com resultados discretos. Os autores descrevem três casos da doença, em adultos, dois do sexo feminino e um do sexo masculino, com lesões características - pápulas que se tornavam confluentes no centro e reticuladas na periferia, formando placas de limites imprecisos, ligeiramente descamativas - e discutem aspectos etiológicos e terapêuticos da doença.

Palavras-chave: Dermatopatias; Dermatopatias/etiologia; Hiperpigmentação; Hiperpigmentação/diagnóstico; Papiloma; Papiloma/patologia; Terapêutica

Abstract: Confluent and reticulated papillomatosis of Gougerot and Carteaud is a rare dermatosis of unknown etiology. There are numerous therapeutic options - topical retinoids and systemic retinoids, oral antibiotics, etc, and most present poor results. The authors describe three cases of the disease in two female and one male adult subjects, with characteristic lesions- papules become confluent in the center and reticulated in the periphery-and discuss etiological and therapeutical aspects of the disease.

Keywords: Hyperpigmentation; Hyperpigmentation /diagnosis; Papilloma; Papilloma/pathology; Skin diseases; Skin diseases/etiology; Therapeutics.
\end{abstract}

\section{INTRODUÇÃO}

A papilomatose confluente e reticulada (PCR) foi descrita pelos dermatologistas franceses Gougerot e Carteaud, em 1927. ${ }^{1}$ Sua etiologia se mantém obscura, tendo como principais hipóteses, na tentativa de explicar seu surgimento, tratar-se de uma desordem da queratinização ou uma resposta anormal a microorganismos da biota cutânea, tendo, neste último caso, como principais responsáveis, as leveduras lipofílicas do gênero Malassezia. ${ }^{2,3}$

É dermatose rara, que aparece mais freqüentemente em mulheres e melanodérmicos, com maior incidência dos 10 aos 35 anos. Os indivíduos acometidos apresentam tendência à obesidade e à pele seborréica. ${ }^{1}$ Têm sido sugeridas associações com endocrinopatias ou atopia. A ocorrência parece ser esporádica, embora casos entre irmãos tenham sido descritos. ${ }^{4}$

Caracteriza-se clinicamente por pápulas rugosas, planas, pouco salientes, de coloração variável, hipocrômica, rósea ou acastanhada, de até $5 \mathrm{~mm}$. As pápulas tornamse confluentes no centro e reticuladas na periferia, formando placas de limites imprecisos, ligeiramente descamativas; mais raramente, assumem aspecto pseudo-atrófico. As lesões localizam-se nas regiões interescapular, epigástrica e

\footnotetext{
Recebido em 30.8.2005.

Aprovado pelo Conselho Consultivo e aceito para publicação em 13.6.07.

* Trabalho realizado na Escola de Medicina da Santa Casa de Misericórdia de Vitória (Emescam) - Vitória (ES), Brasil.

Conflito de interesse: Nenhum / Conflict of interest: None

Suporte financeiro: Nenhum / Financial funding: None

Pós-graduando do Serviço de Dermatologia da Escola de Medicina da Santa Casa de Misericórdia (Emescam) - Vitória (ES), Brasil.

Professora-assistente do Serviço de Pós-Graduação em Dermatologia da Escola de Medicina da Santa Casa de Misericórdia (Emescam) - Vitória (ES), Brasil.

Especialista em dermatologia pela Sociedade Brasileira de Dermatologia (SBD) - Linhares (ES), Brasil.
} 
intermamária. Nos casos extensos podem comprometer a nuca, a região cervical lateral, os ombros, as axilas e a região pubiana. $^{1,2}$

Tem como principal diagnóstico diferencial a pitiríase versicolor, mas também devem ser lembradas, a acantose nigricante, a amiloidose cutânea, diversas desordens da queratinização e algumas apresentações de dermatite seborréica. $^{1,2}$

O exame histopatológico é pouco característico, encontrando-se alterações sutis, correlacionadas com a apresentação clínica: hiperceratose, geralmente ortoceratósica, papilomatose irregular, acantose predominantemente nas áreas interpapilares e hipogranulose. Também podem ocorrer atrofia focal da camada espinhosa, hiperpigmentação na camada basal, sem alteração no número de melanócitos. Na derme podem ser encontrados cromatóforos na região papilar, discreto infiltrado mononuclear superficial perivascular, leve ectasia de vasos e pequeno a moderado edema papilar. ${ }^{1,2,4-6}$

Histopatologicamente os diagnósticos diferenciais incluem a acantose nigricante, as variantes da ceratose seborréica, o nevo epidérmico do tipo não inflamatório, a doença de Dowling-Degos e o nevo de Becker. ${ }^{4}$

À microscopia eletrônica observa-se aumento da camada de células transicionais entre a camada granulosa e a córnea. Esse fato pode definir a PCR como uma desordem da queratinização de áreas focais da pele, sem elucidar se essa alteração seria primária ou secundária. ${ }^{6}$

São descritas várias opções terapêuticas, como agentes tópicos (ceratolíticos, derivados da vitamina A e D, antimicrobianos) e sistêmicos (antibióticos e retinóides), porém a maioria com resultados inconstantes. ${ }^{3}$

\section{RELATO DOS CASOS}

Caso 1: Paciente do sexo feminino, parda, 25 anos, casada, do lar, residente em Serra, ES. Há dois anos notou aparecimento de manchas hipocrômicas e hipercrômicas, discretamente descamativas no mento, pescoço e nas regiões anterior e posterior do tórax (Figuras 1 e 2).

Fez vários tratamentos para pitiríase versicolor com antifúngicos sistêmicos (cetoconazol, itraconazol, fluconazol), e antifúngicos tópicos, como o sulfeto de selênio, sem resposta favorável.

Após a hipótese diagnóstica de PCR, foram colhidas escamas de manchas do tórax, para a realização de exame micológico direto, cujo resultado foi negativo. A análise da pele através da lâmpada de Wood não demonstrou fluorescência, e o exame histopatológico evidenciou poucas alterações e inespecíficas, como hiperortoceratose compacta e focal, espongiose e discreta acantose (Figura 3).

Caso 2: Paciente do sexo feminino, branca, 22 anos, solteira, auxiliar administrativa, residente em Rio Bananal, ES. Apresentava, desde os 16 anos de idade, lesões no tronco, assintomáticas, com aspecto de placas acastanhadas ou hipocrômicas após descamação, com períodos de melhora e piora (Figuras 4 e 5).

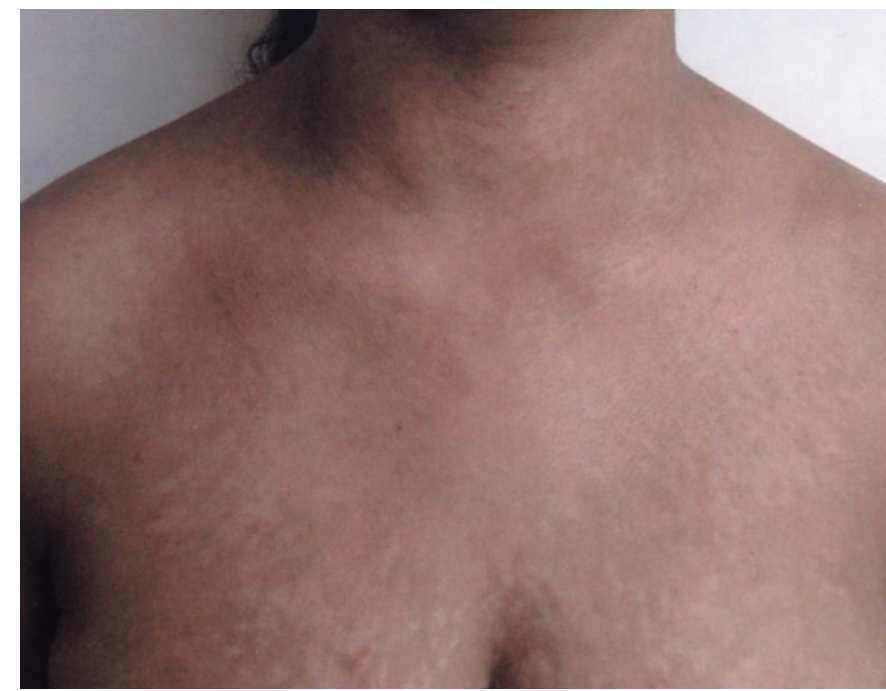

Figura 1: Caso 1: Lesões hipocrômicas e hipercrômicas, discretamente descamativas, confluentes no centro e reticuladas na periferia, no pescoço e região anterior do tórax

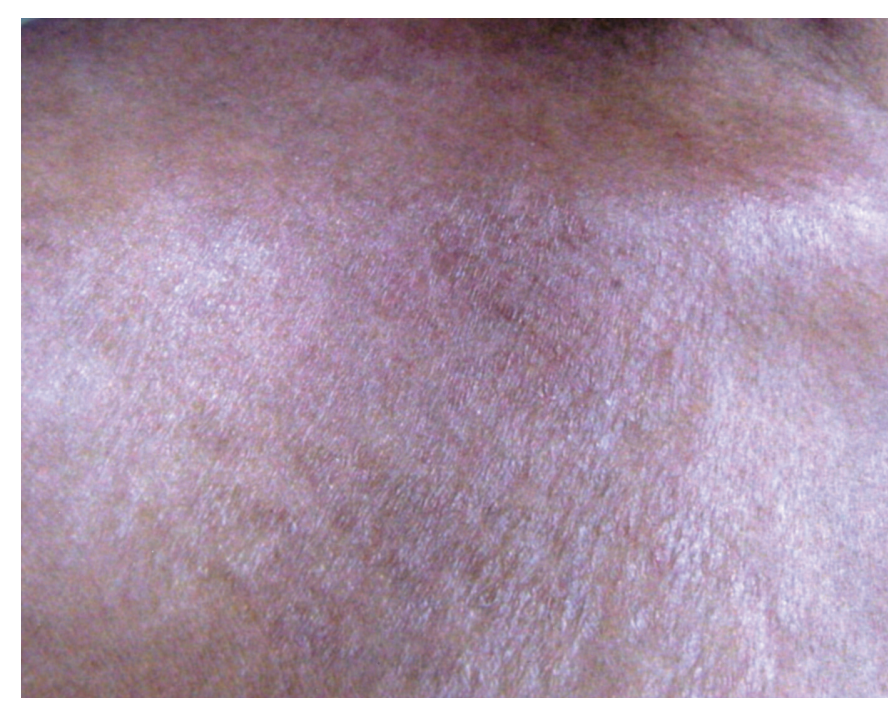

Figura 2: Caso 1: Detalhe das lesões reticuladas

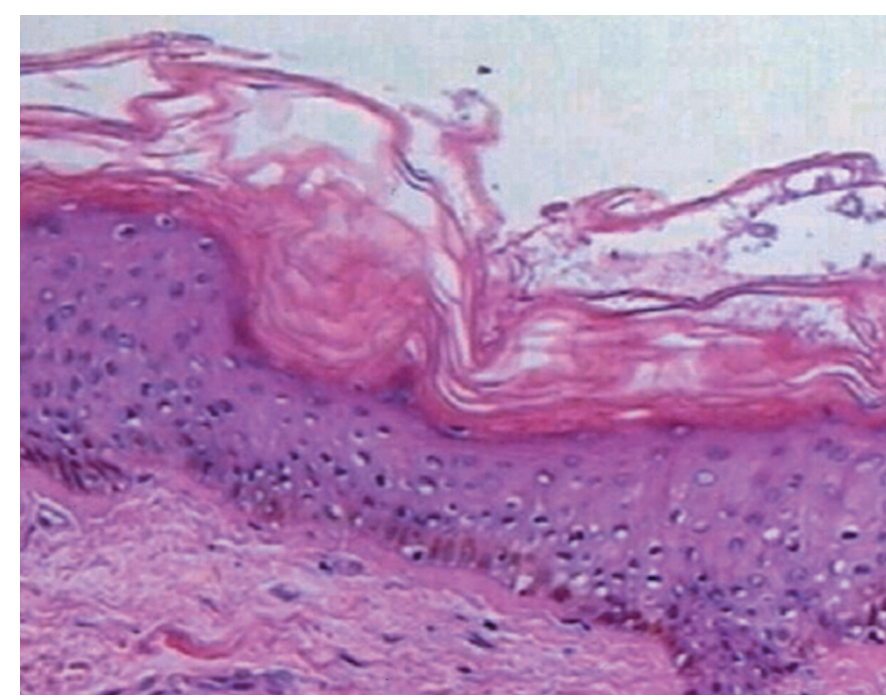

Figura 3: Exame histopatológico. (HE 10x) do caso 1: presença de hiperortoceratose, espongiose e discreta acantose 
O exame histopatológico de uma das lesões evidenciou epiderme com hiperceratose e alongamento dos cones interpapilares. $\mathrm{Na}$ derme superior havia presença de esparsos focos de infiltrado inflamatório linfo-histiocitário e alguns melanófagos perivasculares.

Caso 3: Paciente do sexo masculino, pardo, 25 anos, solteiro, lavrador, residente em Jaguaré, ES. Apresentava desde os 20 anos de idade lesões distribuídas no tronco, região anterior e posterior, na forma de "V", de aspecto ceratósico, de cor acastanhada, alternadas com máculas hipocrômicas após descamação. O exame histopatológico de lesão evidenciou epiderme com hiperceratose, hipogranulose, acantose e derme superior com discreto infiltrado inflamatório linfo-histiocitário.

Os três casos clínicos apresentavam lesões e evolução compatíveis com o diagnóstico de PCR de Gougerot e Carteaud. O caso 1 está sendo tratado com ácido glicólico

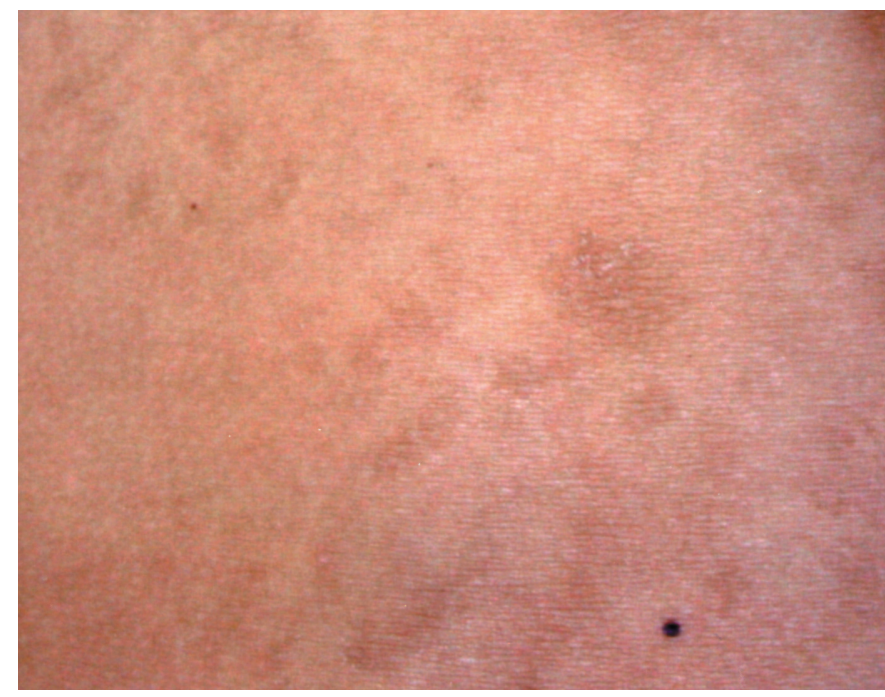

Figura 4: Caso 2: Placas rugosas de aspecto reticulado na região lombar

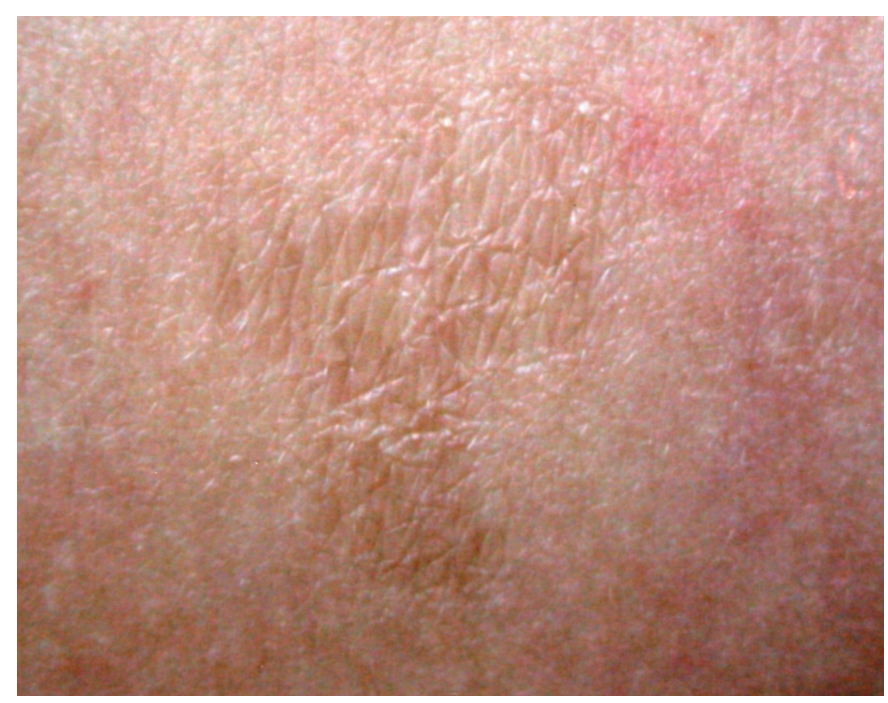

Figura 1: Caso 2: Detalhe de placa rugosa, pouco saliente a $12 \%$ em creme, sendo observada melhora após três meses. O caso 2 está em uso de isotretinoína oral na dose de $20 \mathrm{mg}$ ao dia há dois meses, com melhora do quadro, e o caso 3 não está em tratamento.

\section{DISCUSSÃO}

A PCR de Gougerot e Carteaud é afecção provavelmente subdiagnosticada, 4 com cerca de uma centena de casos relatados na literatura, sendo três deles de publicação brasileira. Corroborando os dados da literatura, a média de idade de início da dermatose dos três casos foi de 20 anos, dois pacientes eram pardos, e tinham índice de massa corpórea superior a 25 , eram do sexo feminino e todos apresentavam pele seborréica. Por outro lado, não foi identificada nenhuma doença concomitante nos três casos.

Muitas dúvidas persistem sobre essa dermatose, principalmente em relação a sua etiopatogenia e seu tratamento. Algumas hipóteses tentam explicar a etiologia da PCR como deficiência de vitamina A, fatores genéticos, fotossensibilidade, anormalidades endócrinas, amiloidose cutânea, reação tecidual à colonização da pele por leveduras lipofílicas do gênero Malassezia, estafilococos ou Propionibacterium acnes e, principalmente, defeito da queratinização. ${ }^{4,-9}$

Como a etiopatogenia permanece desconhecida, são vários os tratamentos propostos, como antibióticos orais (minociclina, doxiciclina, ácido fusídico, claritromicina, eritromicina e azitromicina), sulfeto de selênio, calcipotriol, radioterapia, luz ultravioleta, extrato de tireóide, 5fluorouracil, hidroquinona, progesterona, coaltar, ácido salicílico, uréia, nitrogênio líquido, dermoabrasão, retinóides tópicos (ácido retinóico e tazaroteno) e sistêmicos (isotretinoína, etretinato). ${ }^{3,7}$

As respostas aos retinóides sustentam a teoria de a doença ter como causa alguma desordem da queratinização. Tem sido preconizado o uso de isotretinoína oral um a $2 \mathrm{mg} / \mathrm{kg} / \mathrm{dia}$, com resposta favorável em dois meses. Os pacientes dos casos 2 e 3 foram tratados inicialmente com antifúngicos orais e tópicos, e apresentaram melhora parcial entre os primeiros $15 \mathrm{e}$ 30 dias. Essa melhora clínica também foi observada por Shimizu e colaboradores, favorecendo a hipótese da existência de algum agente infeccioso desencadeando o processo. Isso também explicaria a boa resposta obtida com o uso da minociclina oral $(200 \mathrm{mg} / \mathrm{dia}$ por 10 semanas, com resposta em duas semanas), embora os efeitos antianabólicos e antiinflamatórios das tetraciclinas possam contribuir para a melhora do quadro clínico. ${ }^{7,8}$

Parece razoável supor que a PCR de Gougerot e Carteaud tenha etiopatogenia multifatorial, assim como outras doenças, como acne vulgar, rosácea e dermatite seborréica, o que ajudaria a explicar as respostas terapêuticas a agentes com mecanismos de ação tão diferentes. 


\section{REFERÊNCIAS}

1. Bopp C, Bakos L. Papilomatose papulosa confluente e reticulada. An Bras Dermatol. 1969;44:89-105.

2. Dias MFRG, Azulay RD. Ceratoses foliculares. In: Azulay RD, Azulay DR, editores. Dermatologia. 3 ed. Rio de Janeiro: Guanabara Koogan; 2004. p.452-5.

3. DiGiovana JJ. Ichthyosiform dermatoses. In: Freedberg IM, Eizen AZ, Wollf K, Austin KF, Goldsmith LA, Kats S, et al. Dermatology in General Medicine. 6 ed. New York: Mc Graw-Hill; 1999.p.481-505.

4. Berger CM. Clinical pathological challenge: confluent and reticulated papillomatosis of Gougerot and Carteaud. Am J Dermatophatol. 2003;25:179-80.

5. Soares MA, Rodrigues TS, Kede MPV, Nascimento LV. Papilomatose confluente e reticulada de GougerotCarteaud. An Bras Dermatol. 1992;67:287-8.

6. Lee SH, Choi EH, Lee WS, Kang WH, Bang D. Confluent and reticulated papillomatosis: a clinical, histopathologi cal, and electron microscopic study. J Dermatol. 1991; 18:725-30.
7. Bowman PH, Davis LS. Confluent and reticulated papillo matosis: response to tazarotene. J Am Acad Dermatol. 2003;48(5 Suppl):S80-1.

8. Shimizu S, Han-Yaku H. Confluent and reticulated papillomatosis responsive to minocycline. Dermatology. 1997; 194:59-61.

9. Montemarano CPTAD, Hengge M, Sau COLP, Welch MAJM. Confluent and reticulated papillomatosis: response to minocycline. J Am Acad Dermatol. 1996;34:253-6.

ENDEREÇO PARA CORRESPONDÊNCIA / MAILING ADDRESS: Leonardo Mello Ferreira Av. Governador Lindenberg $10663^{\circ}$ andar, centro 29900202 - Linhares - ES

Tel.: (27) 32641908

E-mail: leonardomellof@gmail.com

Como citar este artigo/How to cite this article: Ferreira LM, Diniz LM, Ferreira CJM. Papilomatose confluente e reticulada de Gougerot e Carteaud: relato de três casos. An Bras Dermatol. 2008;84(1):78-81. 